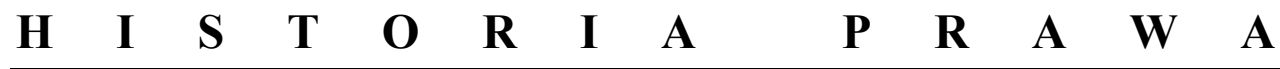

KOŚCIÓ£ I PRAWO 9(22) 2020, nr 2, s. 207-215

DOI: http://dx.doi.org/10.18290/kip2092-14

\author{
Waldemar Bednaruk
}

\section{PRZYMUSOWE UBEZPIECZENIA BUDOWLI KOŚCIELNYCH W MIĘDZYWOJENNEJ POLSCE}

Niewątpliwie najbardziej wartościowym składnikiem majątku, wymagającym szczególnej ochrony, pozostawały przez wieki budynki. Ich zniszczenie pozbawiało ludność dachu nad głową, prowadząc niejednokrotnie do ruiny, a nawet śmierci mieszkańców. Najczęstszą przyczyną nieszczęśliwych wypadków prowadzących do utraty budowli były pożary. Stąd pomysł, by w pierwszej kolejności ubezpieczać najcenniejszą część majątku od występującego najczęściej ryzyka. Problemem jednak pozostawał fakt, iż asekuracja wartościowych walorów pociągała za sobą konieczność ponoszenia dużych ciężarów z tym związanych. Składka od polisy o dużej wartości musiała opiewać na znaczącą sumę, przeważnie na tyle wysoką, że była nie do udźwignięcia dla osób o nieregularnych i niskich dochodach, posiadających nieruchomości o znacznej wartości.

Stąd od początku na drodze do realizacji idei masowych ubezpieczeń stała konieczność pobierania wysokiej składki. Koncepcja przymusowych ubezpieczeń zakładała, iż poprzez powszechny obowiązek udziału w systemie dojdzie do takiego obniżenia składki, iż nie będzie ona stanowić istotnej dolegliwości dla właścicieli polis. Realizowano ją z powodzeniem na

PROF. DR HAB. WALDEMAR BEDNARUK - Katedra Historii Ustroju i Prawa, Instytut Nauk Prawnych, Wydział Prawa, Prawa Kanonicznego i Administracji, Katolicki Uniwersytet Lubelski Jana Pawła II; e-mail: wbednaruk@kul.pl; https://orcid.org/00000002-0080-9470 
zachodzie Europy, a na nasze ziemie dotarła poprzez regulacje wprowadzone przez zaborcę pruskiego.

Kościół katolicki posiadał na ziemiach polskich szereg budowli o znacznej wartości, które ze względu na materiał, z jakiego niektóre z nich zostały wykonane, były bardziej odporne na ryzyko wybuchu pożaru. Przeważnie umiejscawiano je również w pewnej odległości od pozostałych zabudowań, co ograniczało możliwość przeniesienia na nie ognia zaprószonego w innym miejscu. Tak więc były mniej narażone od nieruchomości prywatnych, jednak i tam zdarzały się pożary, przynoszące każdorazowo znaczne straty. Stąd też tam, gdzie wprowadzono przymus ubezpieczenia i one zostały objęte obowiązkiem asekuracji wraz z pozostałymi nieruchomościami.

\section{PIERWSZE LATA NIEPODLEGEOŚCI}

W pierwszych miesiącach istnienia niepodległego państwa polskiego na jego terytorium funkcjonowały obok siebie różne systemy prawne i odmienne regulacje również w odniesieniu do ubezpieczenia majątków. Na obszarze zaboru pruskiego, gdzie w pierwszej kolejności wprowadzano przymusowe ubezpieczenia budowli od ognia, zrezygnowano $\mathrm{z}$ obowiązkowej asekuracji w 1864 r. ${ }^{1}$ Na terenie dawnego Królestwa Polskiego istniał przymus ubezpieczania praktycznie wszystkich nieruchomości od ognia, w tym również budowli kościelnych. Działał na tym obszarze państwowy monopolista w postaci Ubezpieczeń Wzajemnych od ognia, który ściągał obowiązkowe składki, zapewniając asekurację budowli na wypadek pożaru. Na pozostałych terenach początkowo pozostawiono możliwość dobrowolnego asekurowania wszelkich dóbr².

Stan ten jednak traktowano jako przejściowy i jeszcze w trakcie trwania I wojny światowej rozpoczęto prace nad projektem jednolitego systemu ubezpieczeń, obejmującego całe terytorium przyszłego państwa polskiego ${ }^{3}$. Jednocześnie trwała debata dotycząca katalogu budowli objętych obowiąz-

\footnotetext{
${ }^{1}$ Szerzej zob. Sangowski 1988, 17.

${ }^{2}$ Dekret Naczelnika Państwa z dnia 7 lutego 1919 r. w przedmiocie przepisów tymczasowych dla Ubezpieczeń Wzajemnych budowli od ognia w b. Królestwie Polskim, Dz. P. P. P., Nr 14, poz. 190.

${ }^{3}$ Korespondencja w sprawach ubezpieczeń Gabinetu Cywilnego z Ministerstwem Skarbu, luty 1918 r., rkps Archiwum Akt Nowych, Zespół Gabinetu Cywilnego Rady Regencyjnej, sygn. 170, k. 3n.
} 
kiem ubezpieczenia. Pojawiały się w niej pytania o zasadność obejmowania przymusem różnych kategorii nieruchomości, w tym również kościelnych [Dębski 1958, 206n.].

Specjaliści wskazywali, iż system może sprawnie działać pod warunkiem, iż będzie powszechny. Miało to pozwolić na utrzymywanie składek na dość niskim poziomie w stosunku do wartości asekurowanych majątków. Dlatego godzili się, by wyłączyć z niego jedynie budynki o wyjątkowym niebezpieczeństwie pożaru, takie jak składy materiałów wybuchowych i łatwopalnych, natomiast wszystkie inne, w tym również kościelne, należało w nim pozostawić [tamże, 207n.].

W debacie akcentowano dwa podstawowe argumenty na rzecz przymusu asekuracji nieruchomości kościelnych: jeden oczywisty, czyli możliwość odbudowy zniszczonego budynku po pożarze, jaką zapewniały środki z polisy; drugi mniej eksponowany, to dobro pozostałych ubezpieczonych. Ten drugi podkreślali specjaliści związani z branżą ubezpieczeń, akcentując problemy, czy wręcz niemożność funkcjonowania rynku w sytuacji, gdy klientami pozostają wyłącznie podmioty z grupy wysokiego ryzyka [Chomicz 1919, 16n.].

Te głosy na rzecz utrzymania obowiązku asekuracji nieruchomości kościelnych pozostawały w ścisłym związku z wyliczanym bilansem zysków i strat ubezpieczyciela. Największe koszty dla towarzystw ubezpieczeniowych generowały umowy chroniące budowle łatwopalne, czyli te wykonane z drewna i słomy, mieszczące się w zwartej zabudowie wsi i małych miasteczek. To one najczęściej płonęły, a pożary przenosiły się na kolejne budynki, powiększając straty wywołane przez ogień [tamże] ${ }^{4}$.

Oczywiście zakłady ubezpieczeniowe uwzględniały większe ryzyko zniszczenia tego typu budowli, zwiększając składkę, uzależniając wypłatę odszkodowania od spełnienia kolejnych warunków oraz wymuszając określone zachowania zabezpieczające przed możliwością zaprószenia ognia. Jednak nigdy nie były to środki wystarczające do zbilansowania budżetu ubezpieczycieli. Ze względów społecznych musieli oni mieć na uwadze fakt, iż największe grupy ryzyka mieszczą się wśród nieruchomości należących do grona najbiedniejszych obywateli, więc podwyższanie ciężarów polisy do poziomu opłacalności dla towarzystwa prowadziło do buntów ludności, odmowy płacenia składek, zaległości w ich uiszczaniu, a nawet do celowego

\footnotetext{
4 Sprawozdanie Polskiej Dyrekcji Ubezpieczeń Wzajemnych za lata 1923-1924, Warszawa 1925, s. 37n.
} 
podpalania swoich budynków, by wyłudzić odszkodowanie w sytuacji, gdy obciążenia stawały się nie do udźwignięcia ${ }^{5}$.

Ubezpieczyciele prowadzili stały monitoring zachowań klientów w określonej sytuacji. Badano wpływ obciążeń na ilość pożarów i starano się reagować na niekorzystne dla rynku trendy. Najprostszym sposobem uniknięcia zbędnego ryzyka była odmowa podpisania umowy z klientem zbyt obciążonym, a więc takim, który w swojej historii miał już oszustwa ubezpieczeniowe, był o nie podejrzewany albo przedmiot asekuracji sprawiał wrażenie łatwego do zniszczenia. Każdy zakład chciał mieć w swoim portfelu jak najwięcej bezpiecznych polis, eliminując zbędne ryzyko ${ }^{6}$.

Taka ostrożna i egoistyczna polityka podmiotów z branży ubezpieczeń nie leżała w interesie społecznym, gdyż sama idea obowiązkowych ubezpieczeń zakładała ich powszechność i wynikającą z niej taniość polis. Dlatego państwo zmuszało ubezpieczycieli publicznych do obejmowania asekuracją wszystkich budowli zarówno tych mniej, jak i bardziej niebezpiecznych z punktu widzenia możliwości zniszczenia w wyniku pożaru. Zakłady prywatne miały zagwarantowaną dowolność przy zawieraniu umów, publiczne już nie. Jednak, aby bilans zysków i strat wychodził na plus, w portfelu ubezpieczycieli publicznych musiały być również umowy przynoszące korzyści bez zbędnego ryzyka. I do takich należały polisy obejmujące ochroną budowle kościelne ${ }^{7}$.

Prowadzone w trakcie prac nad ustawą o obowiązkowych ubezpieczeniach badania wykazywały, że w dużych miastach, o zabudowie w znacznej mierze murowanej, ubezpieczyciele notują wysokie zyski z tytułu posiadanych polis. W małych miastach, o zabudowie drewnianej, w miasteczkach i wsiach ponoszą istotne straty. W poszczególnych działach do budowli o wyjątkowo małej palności zaliczano nieruchomości kościelne, budynki użyteczności publicznej i niektóre fabryki. Natomiast młyny, folwarki i zabudowania gospodarcze charakteryzowały się wysokim stopniem palności [Chomicz 1919, 16n.].

Stopień ryzyka znalazł swoje odzwierciedlenie w wysokości przeciętnej opłaty taryfowej z ostatnich lat przed uchwaleniem ustawy o obowiązkowych ubezpieczeniach, co obrazuje poniższa tabela, a mimo to nieruchomo-

\footnotetext{
${ }^{5}$ Szerzej zob. Bednaruk 2019, 161, 265n.

${ }^{6}$ Por. Sprawozdanie Statystyczne Dyrekcji Przymusowych i Dobrowolnych Ubezpieczeń od ognia za rok 1928, Warszawa 1929, s. 2n.

${ }^{7}$ Szerzej zob. Wysznacki 1926, 27n.
} 
ści o najniższym zagrożeniu i przy niskim koszcie polisy przynosiły najwyższy zysk.

Tabela 1. Przeciętna stopa opłaty taryfowej ${ }^{8}$

\begin{tabular}{|l|l|}
\hline Dział nieruchomości & $\begin{array}{l}\text { Stopa opłaty liczona w stosunku } \\
\text { do } 100 \text { rubli }\end{array}$ \\
\hline Miasteczka & $0,80 \mathrm{rb}$ \\
Miasta powiatowe & $0,67 \mathrm{rb}$ \\
Wioski & $0,64 \mathrm{rb}$ \\
Dwory & $0,47 \mathrm{rb}$ \\
Miasta gubernialne & $0,41 \mathrm{rb}$ \\
Budynki użyteczności publicznej & $0,39 \mathrm{rb}$ \\
Kościoły & $0,26 \mathrm{rb}$ \\
\hline
\end{tabular}

Ustawa z 1921 r. stanowiła kolejny etap realizacji planu rozciągnięcia obowiązku asekuracji budowli od ognia na całe terytorium państwa. Na mocy jej postanowień przymus ubezpieczenia rozciągnięto na większość obszaru Rzeczypospolitej, poza ziemiami byłego zaboru pruskiego. Przymusem ubezpieczenia objęto na tym terenie wszystkie budowle poza nieruchomościami stanowiącymi własność państwa, budynkami o wyjątkowym stopniu niebezpieczeństwa ogniowego, tymi przeznaczonymi do rozbiórki oraz posiadającymi charakter tymczasowy ${ }^{9}$.

Jednocześnie wprowadzono w życie nowe taryfy dla poszczególnych działów nieruchomości. Taryfa świątynna przewidywała - w zależności od materiału budowlanego, z jakiego wybudowano nieruchomość - składki w wysokości od 0,4 do 5,4\% wartości budynku rocznie. Natomiast w przypadku kościelnych pomieszczeń tymczasowych, kapliczek oraz zaniedbanych domów modlitwy, naliczano specjalną dopłatę w wysokości 50\% składki podstawowej z tego względu, iż ulegały one najczęściej zniszczeniu w wyniku pożaru [Zarębski 1934, 59n.].

Pierwsze lata po uchwaleniu ustawy o przymusie ubezpieczenia były korzystne dla rynku ubezpieczeń, szczególnie ubezpieczeń przymusowych. $\mathrm{W}$ obliczu stale rosnącej inflacji, z czasem przeradzającej się $\mathrm{w}$ hiperin-

\footnotetext{
${ }^{8}$ Opracowanie własne na podstawie danych z: O składce ogniowej i ubezpieczeniach za rok 1918/1919, druk Archiwum Państwowego w Warszawie oddział w Łowiczu, zespół Akta miasta Łowicza, sygn. 292, k. 3n. Zob. także Chomicz 1919, 17.

${ }^{9}$ Ustawa z dnia 23 czerwca 1921 r. o przymusie ubezpieczenia budowli od ognia i Polskiej Dyrekcji Ubezpieczeń Wzajemnych, Dz. U. Nr 64, poz. 395.
} 
flację, obowiązek ubezpieczania nieruchomości od ognia nie napotykał znaczącego oporu ludności, zaś zjawisko szybkiej utraty wartości pieniądza zniechęcało do działań mających na celu wyłudzanie odszkodowań. Dzięki temu przynajmniej w pierwszym okresie tuż po wejściu w życie nowych rozwiązań branża rozwijała się pomyślnie. Problemy dotknęły towarzystwa ubezpieczeniowe, gdy gwałtowna utrata wartości pieniądza zagroziła stabilności rezerw gromadzonych przez poszczególne zakłady ${ }^{10}$.

\section{PO REFORMIE GRABSKIEGO}

Rynek ubezpieczeń wyszedł z kryzysu inflacyjnego znacznie osłabiony. Część zakładów zbankrutowała, wiele musiało odsprzedać udziały inwestorom zagranicznym. Znacznie lepiej poradzili sobie ubezpieczyciele publiczni, którzy gros swoich dochodów czerpali z ubezpieczeń obowiązkowych i posiadali dzięki temu stabilne źródło przychodów. W nowych warunkach stabilności polskiej waluty zasady rywalizacji między poszczególnymi podmiotami w branży asekuracji uległy zmianie. W dobie walki o wpływy liczyły się możliwości oferowania polis na korzystnych warunkach, dlatego należało dbać szczególnie o tych klientów, którzy przynosili zyski.

Budynki kościelne w całym analizowanym okresie pozostawały tym rodzajem nieruchomości, które zapewniały największe korzyści ubezpieczycielom. Niezmiennie plasowały się na czele stawki budowli o najniższej stopie palności, wyprzedzając w bezpieczeństwie budynki użyteczności publicznej, zaś należne składki uiszczano w tym przypadku z wzorową regularnością. Oczywiście fakt ten wpływał na utrzymywanie taryfy kościelnej na odpowiednio niskim poziomie [tamże].

Przyczyny zachowywania niskiej palności w tej kategorii nieruchomości tkwiły nie tylko w ognioodpornym materiale, z którego w znacznej części zbudowane były budynki kościelne oraz oddaleniu od zwartej zabudowy, co $\mathrm{w}$ poprzednim okresie znacząco poprawiało statystyki. W analizach $\mathrm{z}$ tego okresu wskazywano nowe i coraz ważniejsze powody zniszczeń w tej kategorii asekurowanego mienia. Mianowicie doszukując się przyczyn wybuchu pożaru dostrzeżono coraz większy udział podpaleń w całości czynników powodujących powstanie żywiołu przynoszącego straty w majątku. O ile

\footnotetext{
${ }^{10}$ Szerzej zob. Kozłowski 1924, 1n.
} 
w dobie szalejącej inflacji podpalenia nie stanowiły istotnego problemu dla rynku ubezpieczeń (wypłacane z pewnym opóźnieniem odszkodowania nie odzwierciedlały faktycznej wartości zniszczonego majątku), to po ustabilizowaniu waluty celowe działania na rzecz wywołania pożaru awansowały na czoło w sprawozdaniach ubezpieczycieli ${ }^{11}$.

$\mathrm{Z}$ danych policji wynika, iż znakomita większość tego typu zdarzeń miała charakter oszustw ubezpieczeniowych, których dopuszczali się sami właściciele asekurowanych budowli [Bednaruk 2019, 265n.]. Ubezpieczali oni swoje majątki zwykle powyżej rzeczywistej wartości, by następnie podpalić je i wyłudzić odszkodowanie. W przypadku majątków kościelnych tego typu przestępczości nie odnotowywano, co znacząco poprawiało wyniki ubezpieczycieli w tej kategorii asekurowanych majątków ${ }^{12}$.

$\mathrm{Z}$ podobnym zjawiskiem, poprawiającym wyniki budowli kościelnych w statystykach ubezpieczycieli, mamy do czynienia w przypadku większości pozostałych, wiodących przyczyn wybuchu pożaru. Wskazuje się wśród nich nieostrożne obchodzenie się z ogniem, zabawy dzieci, wadliwą instalację komina i uderzenie pioruna ${ }^{13}$. We wszystkich analizach budynki kościelne wykazują dużą odporność na działanie wyżej wskazanych czynników praktycznie przez cały analizowany okres, co pozytywnie wpływało na rentowność polis obejmujących ochroną nieruchomości kościelne ${ }^{14}$.

${ }^{11}$ Por. Sprawozdanie Statystyczne Dyrekcji Przymusowych i Dobrowolnych Ubezpieczeń od ognia za rok 1928, s. 8n.; Sprawozdanie Statystyczne Dyrekcji Przymusowych i Dobrowolnych Ubezpieczeń od ognia za rok 1929, Warszawa 1930, s. 8n.; Sprawozdanie Statystyczne Dyrekcji Przymusowych i Dobrowolnych Ubezpieczeń od ognia za rok 1932, Warszawa 1933, s. 8n. Zob. także Bednaruk 2018, 531n.

${ }^{12}$ Instrukcja o sposobie zwalczania zbrodniczych podpaleń, Poznań 1932, s. 19. Zob. także Kozłowski 1930, 39; Przestępczość w Rzeczypospolitej Polskiej w 1923 r., Tabele opracowane przez Komendę Główną Policji Państwowej, Archiwum Akt Nowych, zespół Komenda Główna Policji Państwowej, sygn. 1730, k. 1n., oraz Statystyka przestępstw w Polsce za lata 1927-1939. Zestawienia z poszczególnych województw, tabele w zbiorach Archiwum Akt Nowych, zespół Komenda Główna Policji Państwowej, sygn. 89, k. 3n., a także Przestępczość w Polsce w r. 1938. Fotokopie map przeglądowych, w zbiorach Archiwum Akt Nowych, zespół Komenda Główna Policji Państwowej, sygn. 90, zdj. 1-4.

${ }^{13}$ Sprawozdanie Statystyczne Dyrekcji Przymusowych i Dobrowolnych Ubezpieczeń od ognia za rok 1928, s. 8n.; Sprawozdanie Statystyczne Dyrekcji Przymusowych i Dobrowolnych Ubezpieczeń od ognia za rok 1929, s. 8n.; Sprawozdanie Statystyczne Dyrekcji Przymusowych i Dobrowolnych Ubezpieczeń od ognia za rok 1932, s. 8n.

${ }^{14}$ Wiadomości i Zarządzenia Zakładu Ubezpieczeń Wzajemnych w Poznaniu, druk Archiwum Akt Nowych, zespół PZUW, sygn. 3/6, k. 94n.; Olszewski 1925, 23. 


\section{PODSUMOWANIE}

Reasumując stwierdzić należy, iż obowiązkowe ubezpieczenia nieruchomości kościelnych od ognia, utrzymane w całym okresie międzywojennym na znakomitej większości terytorium państwa polskiego, spełniły szereg funkcji. Pamiętać należy oczywiście o tej podstawowej, jaką było zabezpieczenie na wypadek pożaru i możliwość odbudowy zniszczonego przez ogień budynku ze środków wypłaconych zgodnie z umową. Był jednak również inny aspekt, który możemy określić mianem społecznego. Mianowicie ze względu na niewielką palność budowli w tym dziale nieruchomości zyski wypracowywane przez zakłady pozwalały na utrzymywanie na niskim poziomie składek dla klientów biedniejszych, posiadających umowy chroniące majątek narażony na zniszczenie w o wiele większym stopniu.

\section{PIŚMIENNICTWO}

Bednaruk, Waldemar. 2018. „Przyczyny zwiększonej palności nieruchomości ubezpieczonych w PZUW przed II wojną światową.” Krakowskie Studia z Historii Państwa i Prawa 11, nr 4:531-41.

Bednaruk, Waldemar. 2019. Przestępczość ubezpieczeniowa w międzywojennej Polsce. Lublin: Wydawnictwo KUL.

Chomicz, Bolesław. 1919. Ubezpieczenia miejskie. Uwagi nad ich stanem obecnym i przyszłościa. Warszawa: Nakładem Polskiej Dyrekcji Ubezpieczeń Wzajemnych.

Dębski, Jan. 1958. „Z historii walk o społeczny charakter instytucji ubezpieczeń.” W 150 lat ubezpieczeń $w$ Polsce, red. Eugeniusz Kreid, t. 1, 195-208. Warszawa: Polskie Wydawnictwo Gospodarcze.

Kozłowski, Władysław. 1924. „Wyniki działalności polskich zakładów ubezpieczeniowych w ciągu pięciu lat inflacji (1919-1923).” Przegląd Ubezpieczeniowy 3-4:1-7.

Kozłowski, Władysław. 1930. „Zbrodnie na tle ubezpieczeniowem.” Przeglad Ubezpieczeniowy 6:39-40.

Olszewski, Kazimierz. 1925. „Kilka uwag w związku z ostatnimi pożarami.” Przegląd Ubezpieczeniowy 5:23-25.

Sangowski, Tadeusz. 1988. „Rozwój ubezpieczeń gospodarczych na ziemiach polskich w latach 1803-1945." W 185 lat ubezpieczeń gospodarczych w Polsce, red. Tadeusz Sangowski, 9-28. Warszawa: Wydawnicza Oficyna Drukarska Wojewódzkiej Biblioteki Publicznej i Książnicy Miejskiej im. M. Kopernika w Toruniu.

Wysznacki, Konstanty. 1926. Polska Dyrekcja Ubezpieczeń Wzajemnych w historycznym rozwoju. Przyczynek do dziejów ubezpieczeń publicznych w Polsce. Warszawa: Nakładem Polskiej Dyrekcji Ubezpieczeń Wzajemnych.

Zarębski, Franciszek. 1934. „Zagadnienie taryfowe w przymusowem ubezpieczeniu budowli od ognia." W Działalność Powszechnego Zakładu Ubezpieczeń Wzajemnych w latach 1926-1933, red. Władysław Strzelecki, 51-90. Warszawa: Nakładem Powszechnego Zakładu Ubezpieczeń Wzajemnych. 


\title{
Przymusowe ubezpieczenia budowli kościelnych w międzywojennej Polsce
}

\begin{abstract}
Streszczenie
W pierwszych latach istnienia niepodległego państwa polskiego utrzymano, a następnie rozszerzono na nowe tereny, obowiązek ubezpieczania nieruchomości kościelnych od ognia. Ta kategoria budynków została w toku prac nad nowym systemem wyodrębniona. Stworzono dla niej nową taryfę i pobierano niższą składkę z tytułu podpisanych umów. Te preferencyjne warunki naliczania składek wynikały z największej odporności budowli kościelnych na ryzyko pożaru. Materiał, z którego budowano nieruchomości kościelne, ich umiejscowienie oraz odporność na pozostałe czynniki zwiększające niebezpieczeństwo wybuchu pożaru sprawiały, iż budynki kościelne ulegały zniszczeniu bardzo rzadko. Dzięki dobrym wynikom finansowym w tym dziale branża ubezpieczeń mogła oferować lepsze warunki klientom mniej zamożnym, co przyczyniło się do poprawy sytuacji osób najbiedniejszych.
\end{abstract}

Słowa kluczowe: rynek ubezpieczeń; narodziny niepodległego państwa polskiego; przestępczość ubezpieczeniowa

\section{Compulsory Insurance of Church Buildings in Interwar Poland}

\section{Summary}

In the first years of the existence of an independent Polish state, the obligation to insure church real estate against fire was maintained and then extended to new areas. This category of buildings was separated along the way of the works on the new system. A new tariff was set up and a lower payment was charged for signed up contracts. These preferential requirements for calculating contributions follows from the highest resistance of church buildings to the risk of fire. Both the material from which the church properties were built, and their location and resistance to other factors increasing the risk of a fire caused the fact that church buildings were very rarely damaged. Thanks to good financial results in this section, the insurance industry was able to offer better conditions to less affluent clients, which contributed to the improvement of the situation of the poorest people.

Key words: insurance market; independent Polish state; insurance crime

Information about Author: Professor Waldemar Bednaruk, HaB. Ph.D. - Department of History of the System and Law, Institute of Legal Sciences, Faculty of Law, Canon Law and Administration, the John Paul II Catholic University of Lublin; e-mail: wbednaruk@kul.pl; https://orcid.org/0000-0002-0080-9470 